Nota Científica

(Short communication)

\title{
SEMIOCHEMICALS-BAITED TRAPS FOR DETECTING AND ESTIMATING THE POPULATION DENSITY OF SCYPHOPHORUS ACUPUNCTATUS GYLLENHAL (COLEOPTERA: DRYOPTHORIDAE), IN AGAVES, IN TLAQUILTENANGO, MORELOS
}

\author{
TRAMPAS CON SEMIOQUÍMICOS PARA LA DETECCIÓN Y ESTIMACIÓN DE LA \\ DENSIDAD POBLACIONAL DE SCYPHOPHORUS ACUPUNCTATUS GYLLENHAL \\ (COLEOPTERA: DRYOPTHORIDAE), EN AGAVES, EN TLAQUILTENANGO, MORELOS
}

\author{
LAURA FABIOLA CRUZ-JARDÓN ${ }^{1}$, PEDRo FIGUEROA-CASTRO ${ }^{1 *}$, VÍCTOR LÓPEZ-MARTÍNEZ ${ }^{1}$, MARTín \\ PÉREZ-FIGUEROA ${ }^{2}$
${ }^{1}$ Universidad Autónoma del Estado de Morelos, Facultad de Ciencias Agropecuarias, Av. Universidad 1001, Col. Chamilpa, CP 62209, Cuernavaca, Morelos, México. ${ }^{2}$ Productor Independiente de agave, Jojutla, Morelos.
*Autor de correspondencia: <figueroac.pedro@gmail.com>

Recibido: 16/08/2018; aceptado: 26/10/2018; publicado en línea: 10/12/2018

Editor responsable: Arturo Bonet Ceballos

Cruz-Jardón, L. F., Figueroa-Castro, P., López-Martínez, V., Pérez-Figueroa, M. (2018) Semiochemicals-baited traps for detecting and estimating the population density of Scyphophorus acupunctatus Gyllenhal (Coleoptera: Dryopthoridae), in agaves, in Tlaquiltenango, Morelos. Acta Zoológica Mexicana, 34, 1-4. https://doi.org/10.21829/azm.2018.3412163

\begin{abstract}
Scyphophorus acupunctatus Gyllenhal (Coleoptera: Dryophthoridae) is an important pest in agaves, and is the main pest of agaves in Morelos, also this is the first time that the population density of this weevil was sampled in agave plantations in Morelos state using pheromone-baited traps.
\end{abstract}

Cruz-Jardón, L. F., Figueroa-Castro, P., López-Martínez, V., Pérez-Figueroa, M. (2018) Trampas con semioquímicos para la detección y estimación de la densidad poblacional de Scyphophorus acupunctatus Gyllenhal (Coleoptera: Dryopthoridae), en agaves, en Tlaquiltenango, Morelos. Acta Zoológica Mexicana, 34, 1-4. https://doi.org/10.21829/azm.2018.3412163

RESUMEN. Scyphophorus acupunctatus Gyllenhal (Coleoptera: Dryophthoridae) es una plaga importante en agaves y es la plaga más importante en agaves en Morelos. Esta es la primera ocasión que se estudia la densidad poblacional de esta plaga en agaves en Morelos, mediante trampas con feromona.

In Mexico, agaves (Asparagaceae) have great economic importance due to several uses, which the species have (Gentry, 1982; Granados, 1993; Valenzuela, 2011). According to SIAP (2017) there are 105,690 ha cultivated with different agave species. In Morelos state, commercial agaves are growing recently in extension by number of farmers, but this crop is having some important pest as the agave weevil Scyphophorus acupunctatus Gyllenhal, 1838 (Coleoptera: Dryophthoridae). Integrated Pest Management of this weevil in Jalisco is based on adult monitoring with semiochemical-baited traps (Figueroa-Castro et al., 2013; Figueroa, 2014), but this tool has never been tested under Morelos conditions. In order to 
calculate the infestation level of $S$. acupunctatus on agave crops, we conducted a monitoring study with semiochemical-baited traps in Tlaquiltenango, Morelos.

The present research was performed (May - June 2017) in five agave plantations located at the municipality of Tlaquiltenango, Morelos: 1) Plantation "La Era 1", Agave angustifolia Haw., surface 2 ha, 3 years-old (18.552721, -99.099418, $894 \mathrm{~m}$ asl); 2) Plantation "La Era 2", A. angustifolia, surface 2 ha, 3 years-old (18.551373, -99.097901, $885 \mathrm{~m}$ asl); 3) Plantation "El Poste", A. angustifolia, surface 2 ha, 4 years-old (18.563930, -99.093300, $890 \mathrm{~m}$ asl); 4) Plantation "Mezquitera Verde", A. angustifolia, surface 2 ha, 2 year-old (18.564151, -99.084299, $898 \mathrm{~m}$ asl); and, 5) Plantation "Mezquitera azul", A. tequilana $\mathrm{F}$. A. C. Weber, surface 2 ha, 2 year-old (18.563775, -99.084698, 897 masl). In each plantation four traps were placed at ground level, with $50 \mathrm{~m}$ between traps.

Traps were handmade (design TOCCI, Figueroa-Castro et al., 2016). Each trap was baited with a dispenser of synthetic aggregation pheromone Tequilur ${ }^{\circledR}$ (Ferocomps, México) plus $400 \mathrm{~g}$ of ripped banana fruit, as recommended by Figueroa-Castro et al. (2017) sprinkled with the insecticide clorpirifos ethyl (Losrban 480 EM, Dow Agrosciences, Mexico). Traps were checked and give service biweekly. Trapped weevils were kept in ethyl alcohol at $70 \%$ and were taken at "Laboratorio de Producción Agricola del Campo Experimental de la Facultad de Ciencias Agropecuarias de la Universidad Autónoma del Estado de Morelos" for recording males/females using a stereoscopic microscope according to the

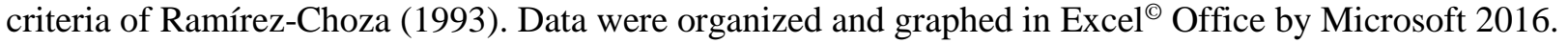

Agave weevil was collected (May - June 2017) in all agave plantations sampled (Table 1), confirming the potential of pheromone-baited traps as a tool for detecting and monitoring the weevil density in agave plantations (Figueroa-Castro et al., 2013). Agave weevil were detected in high numbers at the "El Poste" plantation (the oldest plantation studied). The lowest number of captured weevils were recorded on "Mezquitera Azul" and "Mezquitera verde" both two years old plantations (the youngest plantations). It was observed that the age plants may have a strong influence on agave weevil response, for example Waring and Smith (1986) observed that the agave weevil prefer blooming wild agave plants compare to no blooming wild agave plants.

The mean number of weevils captured in these agave plantations is lowest than captures of this pest on the tuberose crop (Polianthes tuberosa L.) in Morelos (López-Martínez et al., 2011) and in blue agave in Jalisco (Figueroa-Castro et al., 2013) using the same trap design, but it is higher than captures in mezcal agave in Guerrero (Figueroa-Castro et al., 2017). The presence of this pest in all the sampled agave plantations may be due to that in Morelos State there are several wild agave plants that are attacked by this pest. In Morelos the tuberose plant crop P. tuberosa is also an important host of this weevil (Camino-Lavin et al., 2002; López-Martínez et al., 2011).

By the other hand, sexual proportion of weevil showed an irregular pattern between agave plantations (Table 1), where more females were collected in two plantations (La Era 1 and La Era 2), more males in two (Mezquitera verde and Mezquitera azul), and in "El Poste" this proportion was 1:1. In contrast, Figueroa-Castro et al. (2013) found more females than males in traps with this synthetic pheromone in blue agave tequilero plantations.

Based in our results we can confirm that agave weevil has an important phytosanitary risk to agave plantations in Morelos, and future studies should be conducted to try and implement control strategy for developing an integrated pest management program against the agave weevil. This infestation levels are lower compare to those detected in Jalisco state (Figueroa-Castro et al., 2013), but are higher than those infestations levels found in Guerrero state (Figueroa-Castro et al., 2017). 
Table 1. Mean number of Scyphophorus acupunctatus captured per trap biweekly in different agave plantations in the Municipality of Tlaquiltenango, Morelos.

\begin{tabular}{llccc}
\hline \multirow{2}{*}{ Plantation } & \multirow{2}{*}{ agave kind } & \multirow{2}{*}{ weevils/trap/biweekly } & \multicolumn{2}{c}{ Sexual rate (\%) } \\
\cline { 4 - 5 } & Espadín oaxaqueño & 22.75 & 52.14 & Males \\
\hline La Era 1 & Espadín oaxaqueño & 28.83 & 67.08 & 32.96 \\
La Era 2 & Espadín oaxaqueño & 34.92 & 50.67 & 49.33 \\
El Poste & 21.58 & 45.14 & 54.86 \\
Mezquitera Azul & Tequilero & 18.42 & 34.96 & 65.04 \\
Mezquitera Verde & Espadín oaxaqueño &
\end{tabular}

ACKNowledgments. We thank to Ing. Martín Pérez Figueroa, for all the facilities given in the agave plantations. Also to M. C. Francisca Silva García, Ing. Gloria Luna Alejandro, Ing. Daniel Cuevas López and Ing. Francisco Muñoz Santillán for their unvaluable help in the field work.

\section{LITERATURA CITED}

Camino-Lavin, M., Castrejón-Gómez, V., Figueroa-Brito, R., Aldana-Llanos, L., Valdes-Estrada, M. E. (2002) Scyphophorus acupunctatus (Coleoptera: Curculionidae) attacking Polianthes tuberosa (Liliales: Agavaceae) in Morelos, Mexico. Florida Entomologist, 85 (2), 392-393.

Figueroa, C. P. (2014) Factores asociados a la trampa y al atrayente que influyen en la eficiencia del sistema de trampeo para el monitoreo del picudo del agave. Tesis Doctoral. Postgrado en Fitosanidad, Colegio de Postgraduados, Montecillo.

Figueroa-Castro, P., Solís-Aguilar, J. F., González-Hernández, H., Rubio-Cortés, R., HerreraNavarro, E. G., Castillo-Márquez, L. E., Rojas, J. C. (2013) Population dynamics of Scyphophorus acupunctatus (Coleoptera: Curculionidae) on blue agave. Florida Entomologist, 96, 1454-1462.

Figueroa-Castro, P., López-Martínez, V., Hernández-Ruiz, A., Silva-García, F., Campos-Figueroa, M. (2016) Determining the best pheromone-baited traps for capturing Scyphophorus acupunctatus (Coleoptera: Dryophthoridae) in mezcal agave. Florida Entomologist, 99, 790-792.

Figueroa-Castro, P., López-Martínez, V., Silva-García, F., González-Hernández, H. (2017) Food attractants to increase pheromone-baited trap performance for Scyphophorus acupunctatus (Coleoptera: Dryophthoridae) in mezcal maguey. Florida Entomologist, 100 (1), 203-205.

Gentry, H. S. (1982) Agaves of Continental North America. University of Arizona Press. Tucson. Manufactured in the U. S. A. 670 p.

Granados, S. D. (1993) Los Agaves en México. Universidad Autónoma Chapingo.1 a edición. Chapingo, México. 252 p.

López-Martínez, V., Alia-Tejacal, I., Andrade-Rodríguez, M., García-Ramírez, M. J., Rojas, J. C. (2011) Daily activity of Scyphophorus acupunctatus (Coleoptera: Curculionidae) monitored with pheromone-baited traps in a field of Mexican tuberose. Florida Entomologist, 94 (4), 1091-1093.

Ramírez-Choza, J. L. (1993) Max del henequén Scyphophorus interstitialis Gylh. Bioecología y control. Serie: Libro Técnico. Centro de Investigación Regional del Sureste. Instituto de Investigaciones Forestales, Agrícolas y Pecuarias. Secretaría de Agricultura, Ganadería y Recursos Hidráulicos, Mérida, Yucatán, México. 127 p.

SIAP (2017) Servicio de Información Agroalimentaria y Pesquera. Anuario Estadístico de la Producción Agrícola. (consulta en línea: http://infosiap.siap.gob.mx:8080/agricola_siap_gobmx/AvanceNacionalCultivo.doConsultado 23/05/2017). 
Cruz-Jardón et al.: Traps with semiochemicals for agave weevil

Valenzuela, A. (2011) A new agenda for blue agave landraces: food, energy and tequila. GCB Bioenergy, $3,15-24$.

Waring, G. L., Smith, R. L. (1986) Natural history and ecology of Scyphophorus acupunctatus (Coleoptera: Curculionidae) and its associated microbes in cultivated and native agaves. Annals of the Entomological Society of America, 79 (2), 334-340. 